UDC $544.65+661.43$

\author{
D. Girenko, O. Shmychkova, A. Velichenko
}

\title{
ELECTROLYSIS OF SODIUM CHLORIDE SOLUTIONS ON Ti/Pt ANODES UNDER CURRENT REVERSAL CONDITIONS
}

\author{
Ukrainian State University of Chemical Technology, Dnipro, Ukraine
}

\begin{abstract}
An increase in the current efficiency of hypochlorite up to $80-85 \%$ and a possible decrease in the current efficiency of chlorate up to $5-8 \%$ are observed if the electrolysis of $\mathrm{NaCl}$ occurs on a pre-reduced $\mathrm{Ti} / \mathrm{Pt}$ electrode surface. However, the time of the electrolysis on a reduced surface is limited and significantly decreases with increasing current density. The need for the reduction of the surface every time before the electrolysis almost negates the practical value of the above results. The duration of the transition from the reduced surface to the oxidized state can be appreciably decreased in low-concentrated solutions of $\mathrm{NaCl}(0.15-0.45 \mathrm{M} \mathrm{NaCl}$ solutions are commonly used in practice to prepare hypochlorite solutions by direct membraneless electrolysis). For instance, the duration of the transition is $1200 \mathrm{~s}$ and only $80 \mathrm{~s}$ in $0.3 \mathrm{M}$ and in $0.15 \mathrm{M}$ solutions, respectively (at $20 \mathrm{~mA} \mathrm{~cm}{ }^{-2}$ ). Moreover, it becomes possible to refuse the procedure of the pre-treatment of the anode and conduct the electrolysis at any duration on the reduced surface under current reversal conditions. If the electrolysis of $0.15 \mathrm{M} \mathrm{NaCl}$ is performed in a «usual» regime at 20-40 $\mathrm{mA} \mathrm{cm}{ }^{-2}$, then the current efficiency of hypochlorite does not exceed $26 \%$ and the current efficiency of chlorate is at least $21 \%$. It is shown that carrying out the electrolysis under current reversal conditions allows increasing the current efficiency of hypochlorite up to $39 \%$ while reducing the current efficiency of chlorate to $5 \%$. An increase in the concentration of $\mathrm{NaCl}$ to $0.3 \mathrm{M}$ improves the performance of reverse electrolysis even more significantly. In this case, the current efficiency of $\mathrm{ClO}^{-}$formation increases to $78 \%$ and the current efficiency of $\mathrm{ClO}_{3}^{-}$formation decreases to $2 \%$.
\end{abstract}

Keywords: platinum, platinized titanium, anode, sodium hypochlorite, chlorate, reverse polarity electrolysis, reverse current.

DOI: $10.32434 / 0321-4095-2020-129-2-36-43$

\section{Introduction}

Sodium hypochlorite is known to be used on a large scale in agriculture, chemical, paint- and lime, food, glass, paper, pharmaceutical, synthetics and waste disposal industries, etc. $\mathrm{NaClO}$ can be effectively used for water purification, bleaching, odor removal and water disinfection. It can be easily stored and transported when it is produced on-site [1].

Sodium hypochlorite solutions exhibit high biological activity against many gram-positive and gram-negative bacteria, most pathogenic fungi, viruses and protozoa [2]. The active components of these solutions (hypochlorite ion and hypochlorous acid) can reduce the resistance of microflora to antibiotics, increase their effectiveness, neutralize toxic metabolites represented by the decay products of microbes, white blood cells and tissues, and eliminate microcirculation disorders of physiological fluids [3]. In modern medical practice, lowconcentrated solutions of sodium hypochlorite, additionally containing $9 \mathrm{~g} \mathrm{~L}^{-1}$ of sodium chloride, are widely used as antiseptic agents for external and local use, as well as for direct detoxification of the body intravenously [3]. Sodium hypochlorite solutions are practically non-toxic, do not cause allergic reactions and their components do not accumulate in humans and animals.

However, the electrochemical synthesis of highpurity solutions of $0.01-0.1 \%$ sodium hypochlorite by electrolysis of low-concentrated sodium chloride solutions remains challenging. The main difficulties here are the choice of electrode materials, configuration and type of electrolyzer and optimization of the conditions of electrolysis [4]. 
The electrochemical synthesis of sodium hypochlorite solutions is most often carried out on composite coatings based on titanium and tin oxides modified with platinum group metals. Anodes, based on $\mathrm{RuO}_{2}-\mathrm{TiO}_{2}$ seem to be the best for the electrolysis of concentrated $\mathrm{NaCl}$ solutions [5,6], whereas it is better to use anodes coated with mixed oxides of titanium, tin and iridium for the electrolysis of lowconcentrated $\mathrm{NaCl}$ solutions (less than $30 \mathrm{~g} \mathrm{~L}^{-1}$ ) [7,8]. However, such anodes are expensive and labor intensive. The proper anode coatings are practically impossible to apply, for example, on the inner surface of a tubular anode when creating coaxial flowthrough electrochemical modules. They poorly tolerate cathodic polarization. The above disadvantages are practically avoided by platinized titanium electrodes, which have a very high corrosion resistance in various aggressive environments, and can work both in the range of high anodic and cathodic polarizations. However, the use of platinum as an electrocatalyst for the oxidation of $\mathrm{Cl}^{-}$is limited by high current efficiencies (CE) of the oxygen evolution reaction and chlorate formation $[9,10]$.

It is known that the surface of platinum can be in reduced and oxidized states [11]. The electrolysis of $\mathrm{NaCl}$ solutions over the entire concentration range most often occurs on the surface of platinum coated with a layer of phase oxides. In this case, the main three parallel processes are realized with comparable rates: (i) the oxidation of $\mathrm{Cl}^{-}$to hypochlorite, (ii) the oxidation of $\mathrm{Cl}^{-}$yielding chlorite and chlorate, and (iii) the reaction of oxygen evolution. On the reduced surface, CE of hypochlorite reaches $90 \%$ when the $\mathrm{CE}$ of $\mathrm{ClO}_{3}^{-}$is less than $10 \%$, while lower electrode polarizations of $400-450 \mathrm{mV}$ are realized [12]. However, during the electrolysis, the reduced surface gradually oxidizes. Layers of labile and then inert chemisorbed oxygen-containing particles begin to form on the Pt surface in the region of low anodic polarizations. The formation of atomic oxygen becomes possible with increasing polarization and phase oxide layers are formed [11]. The formation of phase surface oxides occurs rapidly, and the oxygen evolution proceeds on a completely oxidized surface in a supporting solution. The presence of $\mathrm{Cl}^{-}$in a solution significantly decelerates this process. Chloride ion acts as a depolarizer. When discharging, it interacts with surface oxygen-containing particles, thereby slowing down the oxidation of the surface. Thus, both direct oxidation of $\mathrm{Cl}^{-}$and its oxidation by labile oxygen-containing particles of the $\mathrm{OH}_{\text {ads }}$ type occur on the reduced platinum surface. The formation of hypochlorite proceeds directly on the surface of the platinum phase oxides layer with the participation of strongly bounded (inert) chemisorbed oxygen-containing particles and atomic oxygen on the oxidized surface. The desorption of the products of primary oxidation of $\mathrm{Cl}^{-}$becomes slower, and an increase in the degree of surface filling with active oxygen-containing particles of the $\mathrm{O}_{\text {ads }}$ type leads to a significant increase in the rate of chlorate formation.

However, the platinum surface is easily turned into a reduced state at a short-term cathodic polarization in the region of hydrogen evolution. This feature of the behavior of platinum and platinized titanium can be used by realizing electrolysis under current reversal conditions on two identical platinum electrodes.

The main characteristics of the electrolysis of sodium chloride solutions on platinized titanium electrodes in non-diaphragm electrolysis cells in the periodic current reversal mode are discussed in this paper in order to create affordable and highly efficient electrolyzers for the synthesis of high-purity sodium hypochlorite solutions.

\section{Material and methods}

All chemicals were reagent grade. Electrochemical measurements were carried out in $1 \mathrm{M} \mathrm{HClO}_{4}$ with computer controlled MTech PGP$550 \mathrm{M}$ potentiostat (Ukraine) in a standard temperature-controlled three-electrode cell. All potentials were recorded and reported vs. $\mathrm{Ag} / \mathrm{AgCl} / \mathrm{KCl}$ (sat.). The reference electrode was brought to the working electrode through the Luggin capillary. The temperature was $25 \pm 1^{\circ} \mathrm{C}$.

Platinized Ti anode was obtained by platinum deposition from a nitrite electrolyte on a prepared titanium surface at $10 \mathrm{~mA} \mathrm{~cm}{ }^{-2}$ and $80^{\circ} \mathrm{C} \mathrm{[13].} \mathrm{The}$ surface content of platinum was $2.0 \mathrm{mg} \mathrm{cm}^{-2}$.

The catalytic activity of the obtained anodes with respect to the sodium hypochlorite synthesis reaction was evaluated under the conditions of accumulative electrolysis of $300 \mathrm{~mL}$ of $0.15,0.30$, and $1.0 \mathrm{M} \mathrm{NaCl}$ solutions of in a non-diaphragm cell at $25^{\circ} \mathrm{C}$ for $60 \mathrm{~min}$. Mixing was carried out by a compact mixer.

The concentration of $\mathrm{NaClO}$ and $\mathrm{NaClO}_{3}$ in solutions was determined by iodometric titration [14]. The standard deviation in determining of the concentration does not exceed $\pm 3 \mathrm{mg} \mathrm{L}^{-1}$ and $\pm 2 \mathrm{mg} \mathrm{L}^{-1}$ for sodium hypochlorite and sodium chlorate, respectively. Moreover, standard deviations for current efficiencies are \pm 1.0 and $\pm 0.5 \%$ for hypochlorite and chlorate, respectively.

\section{Results and discussion}

As stated above, the surface of platinum may be in oxidized and reduced states [12]. The platinum surface is free from phase oxides at the cathodic 
polarization in the region of hydrogen evolution. Such state hereinafter will be referred to as a reduced state. A layer of phase oxides is formed on the surface of platinum with the anodic polarization in the region of oxygen evolution. This state hereinafter will be referred to as an oxidized state. Oxidation and surface reduction occurs almost instantly in a supporting electrolyte (for example, in $1 \mathrm{M} \mathrm{HClO}_{4}$ or $1 \mathrm{M}$ $\mathrm{NaClO}_{4}$ ) at the current densities higher than $10 \mathrm{~mA} \mathrm{~cm}{ }^{-2}$. A previously reduced $\mathrm{Ti} / \mathrm{Pt}$ surface during anodic polarization remains in a reduced state for a long time, if more than $0.5 \mathrm{M}$ chloride ion is present in the solution. Chronopotentiograms on a previously reduced $\mathrm{Ti} / \mathrm{Pt}$ sample in a $1 \mathrm{M} \mathrm{NaCl}$ solution at various anode current densities are shown in Fig. 1. An increase in potential more than $1.3 \mathrm{~V}$ characterizes the transition of the surface to the oxidized state. Therefore, the previously reduced platinum surface with an anodic polarization at $80 \mathrm{~mA} \mathrm{~cm}^{-2}, 40 \mathrm{~mA} \mathrm{~cm}{ }^{-2}$ and $20 \mathrm{~mA} \mathrm{~cm}^{-2}$ remains in the reduced state for 700, 1500 and 3000 seconds, respectively. This allows obtaining quasi-stationary current-voltage curves on the reduced $\mathrm{Ti} / \mathrm{Pt}$ surface.

A series of curves recorded in a galvanostatic mode are shown in Fig. 2. Curve 1 was obtained on the oxidized surface of the sample, then the surface was reduced and curve 2 was recorded; further, curve 3 was obtained on the oxidized and finally curve 4 was recorded on the newly reduced surface. The reproducibility of the curves indicates the reproducibility of the surface during sequential oxidation/reduction of the surface of the sample. As one can see from Fig. 2, the surface state significantly affects the polarization of the electrode in the presence of $\mathrm{Cl}^{-}$ions. At $10 \mathrm{~mA} \mathrm{~cm}$, the change in polarization is $430 \mathrm{mV}$, which indicates the electrocatalytic nature of the $\mathrm{Cl}^{-}$oxidation.

Unfortunately, a layer of phase oxides gradually

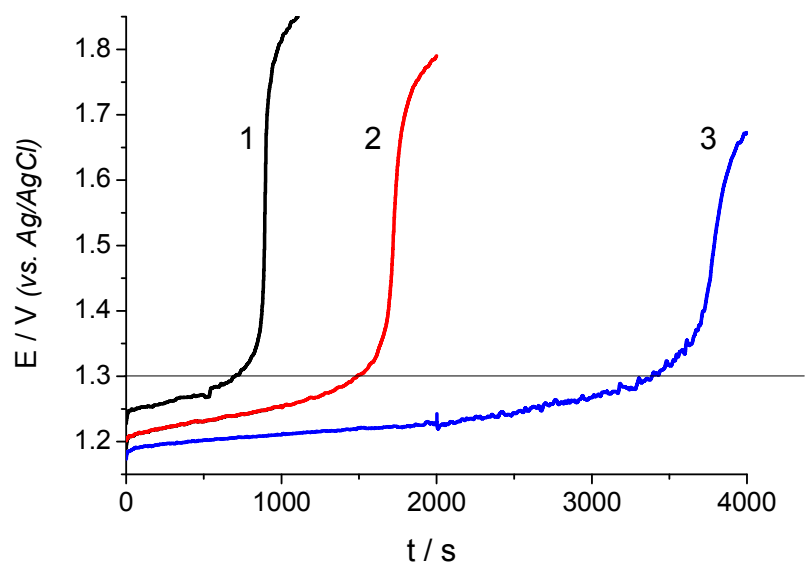

Fig. 1. Chronopotentiograms recorded on reduced $\mathrm{Ti} / \mathrm{Pt}$ electrode at $\mathrm{j}_{\mathrm{a}}=80$ (1), 40 (2) and 20 (3) $\mathrm{mA} \mathrm{cm}^{-2}$ in $1 \mathrm{M} \mathrm{NaCl}$ forms on a platinum surface even in rather highly concentrated $\mathrm{NaCl}$ solutions. Therefore, the potential shifts by almost $500 \mathrm{mV}$ to the anode region and the selectivity with respect to the products of $\mathrm{Cl}^{-}$ion oxidation changes: the $\mathrm{CE}$ of hypochlorite decreases and the CE of chlorate increases [12].

The data obtained after the cumulative electrolysis of $1 \mathrm{M} \mathrm{NaCl}$ solution are given in Table 1 . In order to reduce the influence of the growth of $\mathrm{pH}$ value from the initial 5.5 to 8.5-9.0 during the electrolysis, the initial solution was made alkaline (pH 8.5). To decrease the reduction rate of $\mathrm{ClO}^{-}$ and $\mathrm{HClO}$ on the cathode, the electrolysis was carried out at a minimum rate of electrolyte mixing and at the ratio of cathodic to anodic current densities of 4:1 [15]. The electrolysis duration was $60 \mathrm{~min}$, which does not exceed the time within which the surface was in the reduced state at $20 \mathrm{~mA} \mathrm{~cm}{ }^{-2}$ (Fig. 1). As follows from the results of the experiment, on the reduced surface, the $\mathrm{CE}$ of $\mathrm{ClO}^{-}$is $10-12 \%$ higher than on the oxidized one and is more than $80 \%$. The $\mathrm{CE}$ of $\mathrm{ClO}_{3}{ }^{-}$is almost 2 times higher on the oxidized sample than on the reduced one and is $16 \%$ at $16 \mathrm{~mA} \mathrm{~cm}^{-2}$.

As one can conclude from the obtained results, it is possible to increase the CE of hypochlorite up to $80-85 \%$. In addition, it is possible to reduce the CE of chlorate up to $5-8 \%$, however the duration of the electrolysis on the reduced surface is limited and significantly decreases with increasing current density. The need for reducing the surface every time before the electrolysis almost negates the practical value of the above results. It should be also noted that solutions of $0.15-0.45 \mathrm{M} \mathrm{NaCl}$ are used in practice to prepare hypochlorite solutions by direct membraneless electrolysis. The transition time of the reduced surface to the oxidized state significantly decreases in low-concentrated solutions of $\mathrm{NaCl}$.

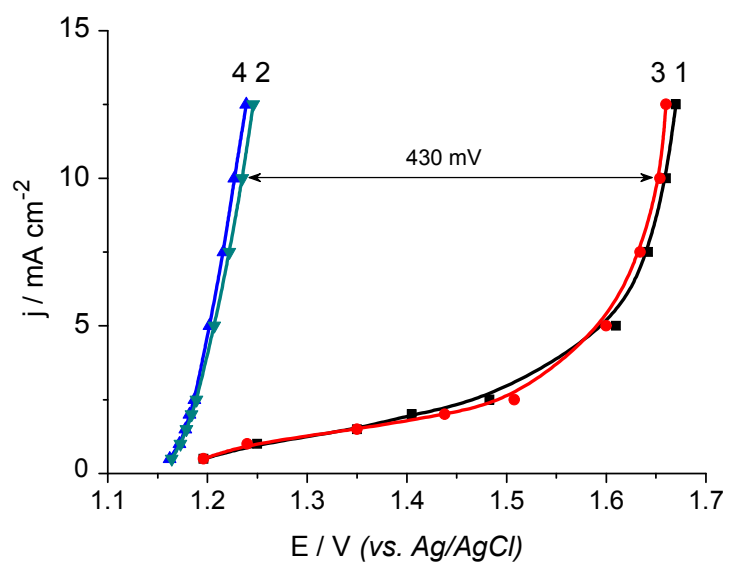

Fig. 2. Steady-state polarization curves recorded on $\mathrm{Ti} / \mathrm{Pt}$ in 2 $\mathrm{M} \mathrm{NaCl}$. The curves numbering is explained in text 
Table 1

Current efficiencies of $\mathrm{NaClO}$ and $\mathrm{NaClO}_{3}$ during one-hour electrolysis in $1.0 \mathrm{M} \mathrm{NaCl}$ on $\mathrm{Ti} / \mathrm{Pt}$

\begin{tabular}{c|c|c|c|c}
\hline \multirow{2}{*}{$\mathrm{j}_{\mathrm{a}}, \mathrm{mA} \mathrm{cm}$} & \multicolumn{2}{|c|}{ Reduced Ti/Pt } & \multicolumn{2}{c}{ Oxidized $\mathrm{Ti} / \mathrm{Pt}$} \\
\cline { 2 - 5 } & $\mathrm{CE}\left(\mathrm{ClO}^{-}\right), \%$ & $\mathrm{CE}\left(\mathrm{ClO}_{3}^{-}\right), \%$ & $\mathrm{CE}\left(\mathrm{ClO}^{-}\right), \%$ & $\mathrm{CE}\left(\mathrm{ClO}_{3}^{-}\right), \%$ \\
\hline 5 & 85 & 5 & 73 & 11 \\
\hline 10 & 83 & 7 & 72 & 13 \\
\hline 20 & 81 & 8 & 71 & 16 \\
\hline
\end{tabular}

For instance, the transition time is $1200 \mathrm{~s}$ in $0.3 \mathrm{M}$ solution, whereas it is only $80 \mathrm{~s}$ in $0.15 \mathrm{M}$ at $20 \mathrm{~mA} \mathrm{~cm}{ }^{-2}$ (Figs. 3 and 4). It is possible to refuse the procedure of the pre-treatment of the anode and conduct the electrolysis with any duration on the reduced surface by performing the electrolysis under current reversal conditions.

It is possible to realize reversible electrolysis in «asymmetric and symmetric» modes. When carrying out the process in an asymmetric mode, the main electrolysis is performed at low anodic and high cathodic current densities $\left(\mathrm{S}_{\mathrm{a}}>\mathrm{S}_{\mathrm{c}}, \mathrm{j}_{\mathrm{c}}>40 \mathrm{~mA} \mathrm{~cm}{ }^{-2}\right)$ in order to decrease the reduction of hypochlorite at the cathode. A short current reverse occurs after a predetermined period to reduce the anode surface. In this way, it is correct to start the electrolysis with the cycle of anode reduction. For the implementation of a symmetric method, the electrodes must be the same and equal in their area. The reverse of the current is done at regular intervals.

The cycle time of the anode polarization can be determined by recording the $\mathrm{E}$ vs. $\mathrm{t}$ dependences on a previously reduced anode at a given current density, solution concentration, and hydrodynamic electrolysis conditions. It should be noted that the time spent by the anode in the reduced state increases as the intensity of mixing of the solution increases

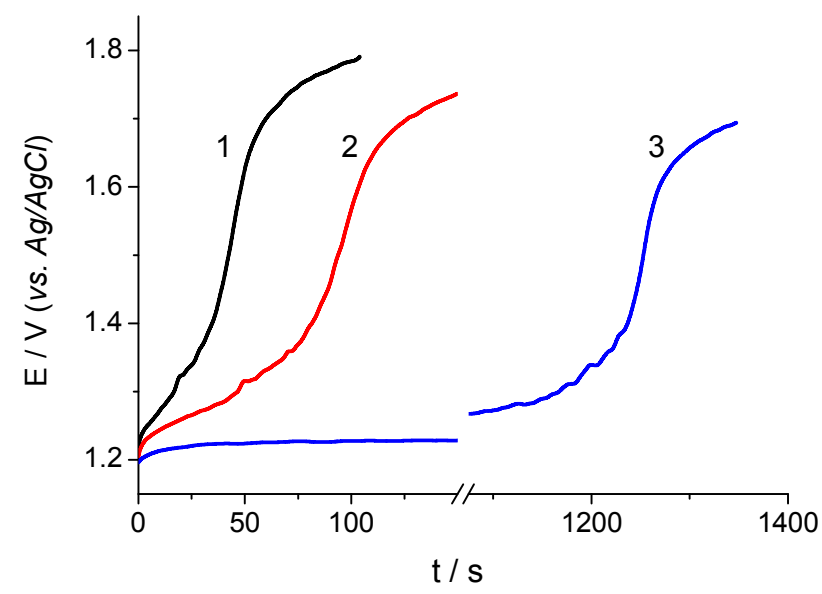

Fig. 3. Chronopotentiograms recorded on reduced $\mathrm{Ti} / \mathrm{Pt}$ electrode at $\mathrm{j}_{\mathrm{a}}=40(1), 30$ (2) and 20 (3) $\mathrm{mA} \mathrm{cm}^{-2}$ in $0.3 \mathrm{M} \mathrm{NaCl}$
(Fig. 5). The chronopotentiograms obtained on the oxidized surface of Ti/Pt in 0.15 and $0.3 \mathrm{M} \mathrm{NaCl}$ solutions by cathodic current polarization are shown in Figs. 6 and 7. As the concentration and the cathode current density increase, the surface reduction time decreases too. However, the transition time to the reduced state does not exceed $15 \mathrm{~s}$ and $5 \mathrm{~s}$ even in $0.15 \mathrm{M} \mathrm{NaCl}$ at $\mathrm{j}_{\mathrm{c}}=-10 \mathrm{~mA} \mathrm{~cm}^{-2}$ and $-20 \mathrm{~mA} \mathrm{~cm}^{-2}$, respectively. A decrease in current density to $5 \mathrm{~mA} \mathrm{~cm}{ }^{-2}$ increases the reduction period up to $100 \mathrm{~s}$ in $0.3 \mathrm{M} \mathrm{NaCl}$ (Fig. 6, curve 4). It should be taken into account that the reverse current density must be at least $10 \mathrm{~mA} \mathrm{~cm}$ co $^{-2}$ to ensure a rapid reduction of the anode surface (up to $15 \mathrm{~s}$ ) when carrying out the reversible electrolysis in asymmetric mode. When performing reversible electrolysis in a symmetric mode, the reversal time is determined by the transition time of the anode to the oxidized state under these conditions of electrolysis. The service life of such electrolysis cells is significantly increased because the anode workload is distributed alternately to both electrodes.

The CE of hypochlorite of $80 \%$ with a sufficiently low CE of chlorate $(5-6 \%)$ is observed at the electrolysis of $1.0 \mathrm{M} \mathrm{NaCl}$ under the current reversal conditions on $\mathrm{Ti} / \mathrm{Pt}$. Compared to standard electrolysis, an increase in $\mathrm{CE}$ of $\mathrm{ClO}^{-}$is almost

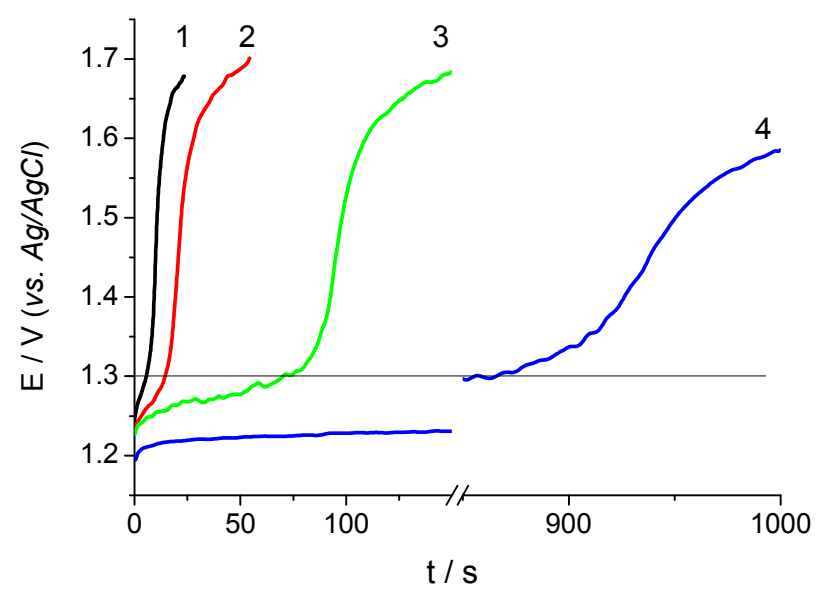

Fig. 4. Chronopotentiograms recorded on reduced Ti/Pt electrode at $\mathrm{j}_{\mathrm{a}}=40$ (1), 30 (2), 20 (3) and 10 (4) $\mathrm{mA} \mathrm{cm} \mathrm{cm}^{-2}$ in $0.15 \mathrm{M} \mathrm{NaCl}$ 


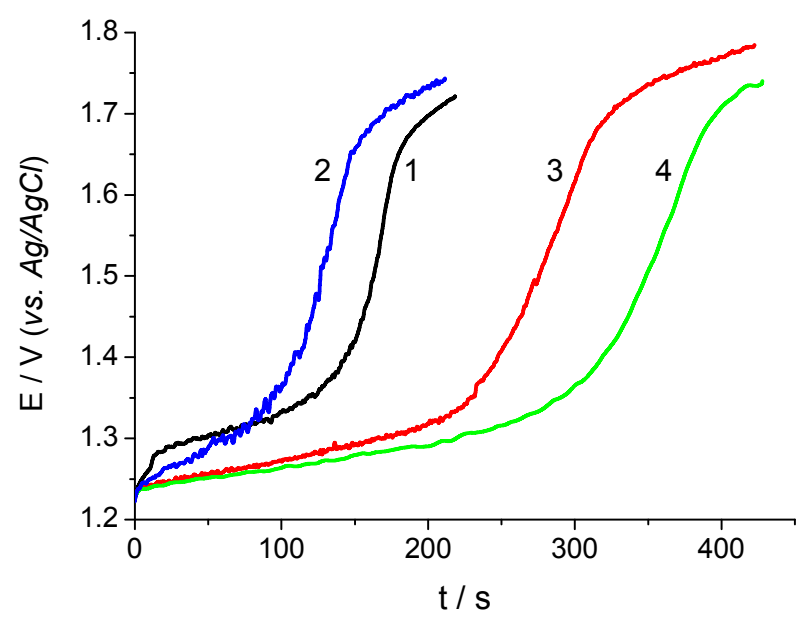

Fig. 5. Chronopotentiograms recorded on reduced $\mathrm{Ti} / \mathrm{Pt}$ electrode at $\mathrm{j}_{\mathrm{a}}=20 \mathrm{~mA} \mathrm{~cm}^{-2}$ in $0.15 \mathrm{M} \mathrm{NaCl}$. Rotational velocity of mixer (rpm): (1) -0 (without mixing), (2) -660 ,

(3) -1400 and $(4)-2000$

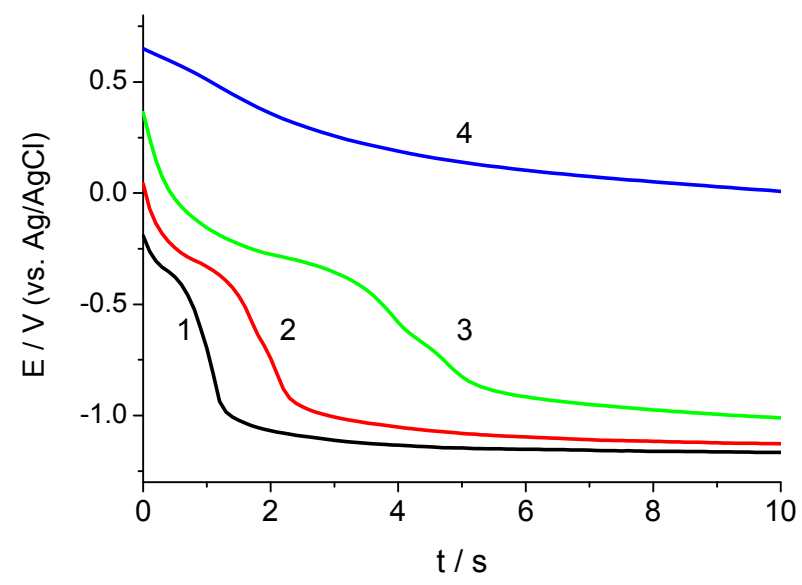

Fig. 6. Chronopotentiograms recorded on oxidized $\mathrm{Ti} / \mathrm{Pt}$ electrode at $\mathrm{j}_{\mathrm{c}}=-20 \mathrm{~mA} \mathrm{~cm}{ }^{-2}(1),-15 \mathrm{~mA} \mathrm{~cm}^{-2}$ (2),

$-10 \mathrm{~mA} \mathrm{~cm}^{-2}$ (3) and -5 (4) $\mathrm{mA} \mathrm{cm}^{-2}$ in $0.3 \mathrm{M} \mathrm{NaCl}$

$10 \%$, and the $\mathrm{CE}$ of $\mathrm{ClO}_{3}^{-}$is decreased by 3 times (Table 2).

When conducting the electrolysis in $0.15 \mathrm{M}$ $\mathrm{NaCl}$ in a non-reversible mode at $20 \mathrm{~mA} \mathrm{~cm}^{-2}$, the integral CEs of hypochlorite and chlorate are comparable and are 26 and $21 \%$, respectively. This indicates the unsuitability of $\mathrm{Ti} / \mathrm{Pt}$ electrodes in the synthesis of hypochlorite in low-concentration solutions. As it has been shown above, the transition

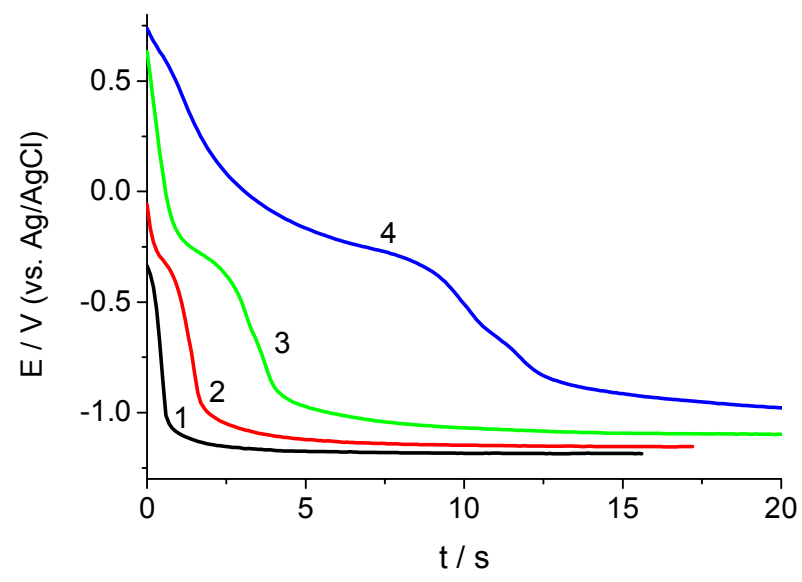

Fig. 7. Chronopotentiograms recorded on oxidized Ti/Pt electrode at $\mathrm{j}_{\mathrm{c}}=-40 \mathrm{~mA} \mathrm{~cm}^{-2}(1),-30 \mathrm{~mA} \mathrm{~cm}^{-2}(2)$,

$-20 \mathrm{~mA} \mathrm{~cm}^{-2}$ (3) and -10 (4) $\mathrm{mA} \mathrm{cm}^{-2}$ in $0.15 \mathrm{M} \mathrm{NaCl}$

time of the reduced surface to the oxidized state in $0.15 \mathrm{M} \mathrm{NaCl}$ is $90 \mathrm{~s}$ and $10 \mathrm{~s}$ at the current density of $20 \mathrm{~mA} \mathrm{~cm}^{-2}$ and $40 \mathrm{~mA} \mathrm{~cm}{ }^{-2}$, respectively. The electrolysis in reverse polarity mode at $20 \mathrm{~mA} \mathrm{~cm}{ }^{-2}$ with a minute period of current direction reversal showed a 1.5-fold increase in CE of hypochlorite (from 26 till 38\%) and a four-fold decrease in CE of chlorate(from 21 to $5 \%$ ). It should be noted that carrying out the reverse electrolysis at $20 \mathrm{~mA} \mathrm{~cm}^{-2}$ with a reverse period exceeding 3 times the surface reduction time $(300 \mathrm{~s})$ practically has no effect on the CE of hypochlorite and chlorate (Table 3).

The composition of the resulting solutions and current efficiencies registered at $40 \mathrm{~mA} \mathrm{~cm}^{-2}$ in the reverse polarity mode with 10 -second reverse time are the same as those observed at $20 \mathrm{~mA} \mathrm{~cm}^{-2}$ and a 60 -second reverse time. At $40 \mathrm{~mA} \mathrm{~cm}^{-2}$ and 10 -second reverse time, $\mathrm{CE}$ of $\mathrm{ClO}^{-}$was $39 \%$ and $\mathrm{CE}$ of $\mathrm{ClO}_{3}^{-}$was $5 \%$. At 60 -second reverse time, $\mathrm{CE}$ of hypochlorite decreases to $31 \%$ and $\mathrm{CE}$ of chlorate grows to $9 \%$ since more than half of the electrolysis time is realized on the oxidized surface of the anode. Accumulative electrolysis was performed under the conditions of the normal and reverse current reversal on platinum-plated electrodes made of porous titanium at an overall current density of $40 \mathrm{~mA} \mathrm{~cm}{ }^{-2}$ in order to compare the effect of the substrate. A rather high CE of hypochlorite (51\%)

Table 2

Current efficiencies of $\mathrm{NaClO}$ and $\mathrm{NaClO}_{3}$ at electrolysis of $1.0 \mathrm{M} \mathrm{NaCl}$ at Ti/Pt electrodes in different modes

\begin{tabular}{l|c|c|c}
\hline \multicolumn{1}{c|}{ Conditions } & $\mathrm{j}, \mathrm{mA} \mathrm{cm}^{-2}$ & $\mathrm{CE}\left(\mathrm{ClO}^{-}\right), \%$ & $\mathrm{CE}\left(\mathrm{ClO}_{3}^{-}\right), \%$ \\
\hline Traditional mode. Anode is pre-oxidized & 20 & 74 & 16 \\
\hline Reverse polarity mode $\left(\mathrm{t}_{\text {rev }}=5 \mathrm{~min}\right)$ & 20 & 84 & 5 \\
\hline Traditional mode. Anode is pre-oxidized & 40 & 71 & 17 \\
\hline Reverse polarity mode $\left(\mathrm{t}_{\mathrm{rev}}=5 \mathrm{~min}\right)$ & 40 & 79 & 6 \\
\hline
\end{tabular}


Current efficiencies of $\mathrm{NaClO}$ and $\mathrm{NaClO}_{3}$ at electrolysis of $0.15 \mathrm{M} \mathrm{NaCl}$ at $\mathrm{Ti} / \mathrm{Pt}$ electrodes in different modes

\begin{tabular}{l|c|c|c}
\hline \multicolumn{1}{c|}{ Conditions } & $\mathrm{j}, \mathrm{mA} \mathrm{cm}$ & $\mathrm{CE}\left(\mathrm{ClO}^{-}\right), \%$ & $\mathrm{CE}\left(\mathrm{ClO}_{3}^{-}\right), \%$ \\
\hline Traditional mode. Anode is pre-oxidized & 20 & 26 & 21 \\
\hline Traditional mode. Anode is pre-oxidized & 40 & 23 & 24 \\
\hline Reverse polarity mode $\left(\mathrm{t}_{\mathrm{rev}}=60 \mathrm{~s}\right)$ & 20 & 38 & 5 \\
\hline Reverse polarity mode $\left(\mathrm{t}_{\mathrm{rev}}=300 \mathrm{~s}\right)$ & 20 & 37 & 7 \\
\hline Reverse polarity mode $\left(\mathrm{t}_{\mathrm{rev}}=10 \mathrm{~s}\right)$ & 40 & 39 & 5 \\
\hline Reverse polarity mode $\left(\mathrm{t}_{\mathrm{rev}}=60 \mathrm{~s}\right)$ & 40 & 31 & 9 \\
\hline Traditional mode. Porous pre-oxidized Ti/Pt anode & 40 & 29 & 14 \\
\hline Reverse polarity mode $\left(\mathrm{t}_{\mathrm{rev}}=300 \mathrm{~s}\right)$. Porous Ti/Pt & 40 & 51 & 5 \\
\hline
\end{tabular}

Table 4

Current efficiencies of $\mathrm{NaClO}$ and $\mathrm{NaClO}_{3}$ at electrolysis of $0.3 \mathrm{M} \mathrm{NaCl}$ at $\mathrm{Ti} / \mathrm{Pt}$ electrodes in different modes

\begin{tabular}{l|c|c|c}
\hline \multicolumn{1}{c|}{ Conditions } & $\mathrm{j}, \mathrm{mA} \mathrm{cm}^{-2}$ & $\mathrm{CE}\left(\mathrm{ClO}^{-}\right), \%$ & $\mathrm{CE}\left(\mathrm{ClO}_{3}^{-}\right), \%$ \\
\hline Traditional mode. Anode is pre-oxidized & 40 & 53 & 13 \\
\hline Reverse polarity mode $\left(\mathrm{t}_{\text {rev }}=50 \mathrm{~s}\right)$ & 40 & 68 & 3 \\
\hline Traditional mode. Anode is pre-oxidized & 20 & 54 & 11 \\
\hline Reverse polarity mode $\left(\mathrm{t}_{\text {rev }}=300 \mathrm{~s}\right)$ & 20 & 78 & 1.5 \\
\hline
\end{tabular}

and low $\mathrm{CE}$ of chlorate $(5 \%)$ were observed in the reverse polarity mode with 300 -second reverse time. Thus, the electrolysis in reverse polarity mode allows solving the problem of chlorate accumulation during the synthesis of sodium hypochlorite for medical and veterinary purposes by electrolysis of isotonic $0.9 \% \mathrm{NaCl}$ solutions on $\mathrm{Ti} / \mathrm{Pt}$ electrodes.

An increase in the concentration of sodium chloride in the initial solution to $0.3 \mathrm{M}$ simultaneously with electrolysis in reverse polarity mode on $\mathrm{Ti} / \mathrm{Pt}$ allows obtaining high-purity solutions of sodium hypochlorite with a CE of the target product up to $78 \%$ and practically free of chlorates (Table 4).

\section{Conclusions}

The electrolysis of $1 \mathrm{M} \mathrm{NaCl}$ solutions on a previously reduced surface of $\mathrm{Ti} / \mathrm{Pt}$ in diaphragmless electrolysis cells allows synthesizing sodium hypochlorite with the current efficiency of more than $80 \%$, the current efficiency associated chlorate being less than $10 \%$. The use of these concentrated solutions is not always advisable. In the course of electrolysis, the platinum surface gradually transforms into an oxidized state. In this case, one must cathodicaly activate the anode every time before the electrolysis.

It is possible to decrease the working concentration of solutions while maintaining high CE of hypochlorite and low CE of chlorates via the electrolysis under the current reversal conditions. If one conducts the electrolysis of $0.15 \mathrm{M} \mathrm{NaCl}$ in a usual mode at $20-40 \mathrm{~mA} \mathrm{~cm}^{-2}$, the $\mathrm{CE}$ of hypochlorite does not exceed 26 and the $\mathrm{CE}$ of chlorate is at least $21 \%$. Carrying out the electrolysis in reverse mode allows increasing the $\mathrm{CE}$ of hypochlorite up to $39 \%$ while reducing the CE of chlorate to $5 \%$. An increase in the concentration of $\mathrm{NaCl}$ to $0.3 \mathrm{M}$ improves the performance of reverse electrolysis even more significantly. In this case, $\mathrm{CE}$ of $\mathrm{ClO}^{-}$reaches $78 \%$ and $\mathrm{CE}$ of $\mathrm{ClO}_{3}^{-}$decreases to $2 \%$.

Thus, platinized titanium electrodes with $2 \mathrm{mg} \mathrm{cm}^{-2}$ platinum content can be used in diaphragmless flow and accumulative electrolysis cells for the electrolysis of low concentration $\mathrm{NaCl}$ solutions in order to obtain highly pure $\mathrm{NaClO}$ solutions. In this case, the electrolysis must be carried out under the current reversal conditions, the period of which is determined in accordance with the specified electrolysis parameters (current density, $\mathrm{NaCl}$ concentration and hydrodynamic conditions).

\section{REFERENCES}

1. Suty H., Traversay D.C., Cost M.R. Applications of advanced oxidation processes: present and future // Water Sci. Technol. - 2004. - Vol.49. - P.227-233.

2. Locker J., Fitzgerald P., Sharp D. Antibacterial validation of electrogenerated hypochlorite using carbon-based electrodes // Lett. Appl. Microbiol. - 2014. - Vol.59. - P.636-641.

3. Mechanism of action of sodium hypochlorite / Estrela C., 
Estrela C.R.A., Barbin E.L., Spano J.C.E., Marchesan M.A., Pecora J.D. // Braz. Dent. J. - 2002. - Vol.13. - P.113-117.

4. Energy optimization and layout of a membrane-free OSEC system for the hypochlorite self-production in developing countries / Dell'Era A., Zuccari F., Santiangeli A., Fiori C., Micangeli A., Orecchini F. // Energy Convers. Manag. -2013. Vol.75. - P.446-452.

5. A review of chlorine evolution mechanism on dimensionally stable anode (DSA $\left.{ }^{\circledast}\right)$ / Kim J., Kim C., Kim S., Yoon J. // Korean Chem. Eng. Res. - 2015. - Vol.53. - P.531539.

6. Cornell A., Hakansson B., Lindbergh G. Ruthenium based $\mathrm{DSA} \otimes$ in chlorate electrolysis-critical anode potential and reaction kinetics // Electrochim. Acta. - 2003. - Vol.48. - P.473-481.

7. Adams B., Tian M., Chen A. Design and electrochemical study of $\mathrm{SnO}_{2}$-based mixed oxide electrodes // Electrochim. Acta. - 2009. - Vol.54. - P.1491-1498.

8. Active $\mathrm{Ti} / \mathrm{SnO}_{2}$ anodes for pollutants oxidation prepared using chemical vapor deposition / Yao P., Chen X., Wu H., Wang D. // Surf. Coat. Tech. - 2008. - Vol.202. - P.3850-3855.

9. On the electrolysis of dilute chloride solutions: Influence of the electrode material on Faradaic efficiency for active chlorine, chlorate and perchlorate / Neodo S., Rosestolato D., Ferro S., De Battisti A. // Electrochim. Acta. - 2012. - Vol.80. - P.282291.

10. Czarnetzki L., Janssen L.J.J. Electrochemical oxidation of hypochlorite at platinum anodes // Electrochim. Acta. - 1988. - Vol.33. - P.561-566.

11. Electrochemical chlorine evolution at rutile oxide (110) surfaces / Hansen H.A., Man I.C., Studt F., Abid-Pedersen F., Bligaard T., Rossmeisl J. // Phys. Chem. Chem. Phys. - 2010. Vol.12. - P.283-290.

12. Girenko D.V., Velichenko A.B. Synthesis of low concentration solutions of sodium hypochlorite in an electrolyzer with undivided electrode space // Voprosy Khimii i Khimicheskoi Tekhnologii. - 2018. - No. 4. - P.82-91.

13. Electrodeposition of $\mathrm{Ni}^{2+}$-doped $\mathrm{PbO}_{2}$ and physicochemical properties of the coating / Shmychkova O., Luk'yanenko T., Amadelli R., Velichenko A. // J. Electroanal. Chem. - 2016. - Vol.774. - P.88-94.

14. Girenko D.V., Gyrenko A.A., Nikolenko N.V. Potentiometric determination of chlorate impurities in hypochlorite solutions // Int. J. Anal. Chem. - 2019. - Vol.2019. - Article No. 2360420.

15. Girenko D.V., Velichenko A.B. Selection of the optimal cathode material to synthesize medical sodium hypochlorite solutions in a membraneless electrolyzer // Surf. Eng. Appl. Electrochem. - 2018. - Vol.54. - P.88-95.

Received 26.11.2019

\section{ЕЛЕКТРОЛІЗ РОЗЧИНІВ НАТРІЙ ХЛОРИДУ НА Ті/Рt АНОДАХ В УМОВАХ РЕВЕРСУВАННЯ СТРУМУ}

\section{Д. Гиренко, О. Шмичкова, О. Веліченко}

При здійсненні електролізу $\mathrm{NaCl}$ на попередньо відновленій поверхні Ti/Pt електроду спостерігається підвищення виходу за струмом гіпохлориту до 80-85\% і можливе зниження виходу за струмом хлорату до 5-8\%. Однак тривалість електролізу на відновленій поверхні обмежений $і$ значно зменшується зі збільшенням густини струму. Необхідність відновлення поверхні перед кожним електролізом фактично зводить нанівець практичну цінність наведених вище результатів. Втім, час переходу відновленої поверхні в окислений стан значно зменшується в низько-концентрованих розчинах $\mathrm{NaCl}$ (на практиці зазвичай для одержання розчинів гіпохлориту прямим безмембранним електролізом використовуються розчини 0,15-0,45 M $\mathrm{NaCl).} \mathrm{Так,} \mathrm{наприклад,} \mathrm{час} \mathrm{переходу} \mathrm{становить} 1200$ с в 0,3 М розчині і тільки 80 с в $0,15 \mathrm{M}$ за 20 мА $\mathrm{cm}^{-2}$. Більи того, можна відмовитися від процедури попереднього оброблення анода $i$ здійснювати електроліз будь-якої тривалості на відновленій поверхні, проводячи електроліз в режимі реверсування струму. Якщо здійснювати електроліз $0,15 \mathrm{M} \mathrm{NaCl}$ в звичайному режимі за 20-40 мА см ${ }^{-2}$, то вихід за струмом гіпохлориту не перевишує 26\%, а вихід за струмом хлорату становить не менше 21\%. Здійснення електролізу в реверсивному режимі дозволяє підвищити вихід за струмом гіпохлориту до $39 \%$ зі зниженням виходу за струмом хлорату до 5\%. Збільшення концентраціі $\mathrm{NaCl}$ до 0,3 М значно покрашуе продуктивність реверсивного електролізу. У цьому випадку вихід за струмом $\mathrm{ClO}^{-}$збільиується до 78\%, а вихід за струмом $\mathrm{ClO}_{3}^{-}$зменшується до $2 \%$.

Ключові слова: платина, платинований титан, анод, натрію гіпохлорит, хлорат, реверсивний електроліз, реверс струму.

\section{ELECTROLYSIS OF SODIUM CHLORIDE SOLUTIONS ON Ti/Pt ANODES UNDER CURRENT REVERSAL CONDITIONS}

\section{Girenko, O. Shmychkova, A. Velichenko *}

Ukrainian State University of Chemical Technology, Dnipro, Ukraine

\section{*e-mail: velichenko@ukr.net}

An increase in the current efficiency of hypochlorite up to 80-85\% and a possible decrease in the current efficiency of chlorate up to 5-8\% are observed if the electrolysis of $\mathrm{NaCl}$ occurs on a prereduced Ti/Pt electrode surface. However, the time of the electrolysis on a reduced surface is limited and significantly decreases with increasing current density. The need for the reduction of the surface every time before the electrolysis almost negates the practical value of the above results. The duration of the transition from the reduced surface to the oxidized state can be appreciably decreased in lowconcentrated solutions of $\mathrm{NaCl}(0.15-0.45 \mathrm{M} \mathrm{NaCl}$ solutions are commonly used in practice to prepare hypochlorite solutions by direct membraneless electrolysis). For instance, the duration of the transition is $1200 \mathrm{~s}$ and only $80 \mathrm{~s}$ in $0.3 \mathrm{M}$ and in $0.15 \mathrm{M}$ solutions, respectively (at $20 \mathrm{~mA} \mathrm{~cm} \mathrm{~cm}^{-2}$. Moreover, it becomes possible to refuse the procedure of the pre-treatment of the anode and conduct the electrolysis at any duration on the reduced surface under current reversal conditions. If the electrolysis of $0.15 \mathrm{M} \mathrm{NaCl}$ is performed in a «usual» regime at $20-40 \mathrm{~mA} \mathrm{~cm}{ }^{-2}$, then the current efficiency of hypochlorite does not exceed $26 \%$ and the current efficiency of chlorate is at least $21 \%$. It is shown that carrying out the electrolysis under current reversal conditions allows increasing the current efficiency of hypochlorite up to $39 \%$ while reducing the current efficiency of chlorate to 5\%. An increase in the concentration of $\mathrm{NaCl}$ to $0.3 \mathrm{M}$ improves the performance of reverse electrolysis even more significantly. In this 
case, the current efficiency of $\mathrm{ClO}^{-}$formation increases to $78 \%$ and the current efficiency of $\mathrm{ClO}_{3}{ }^{-}$formation decreases to $2 \%$.

Keywords: platinum; platinized titanium; anode; sodium hypochlorite; chlorate; reverse polarity electrolysis; reverse current.

\section{REFERENCES}

1. Suty H., Traversay D.C., Cost M.R. Applications of advanced oxidation processes: present and future. Water Science and Technology: a Journal of the International Association on Water Pollution Research, 2004, vol. 49, no. 4, pp. 227-233.

2. Locker J., Fitzgerald P., Sharp D. Antibacterial validation of electrogenerated hypochlorite using carbon-based electrodes. Letters in Applied Microbiology, 2014, vol. 59, pp. 636-641.

3. Estrela C., Estrela C.R.A., Barbin E.L., Spano J.C.E., Marchesan M.A., Pecora J.D. Mechanism of action of sodium hypochlorite. Brazilian Dental Journal, 2002, vol. 13, pp. 113117.

4. Dell'Era A., Zuccari F., Santiangeli A., Fiori C., Micangeli A., Orecchini F. Energy optimisation and layout of a membrane-free OSEC system for the hypochlorite self-production in Developing Countries. Energy Conversion and Management, 2013, vol. 75 , pp. $446-452$.

5. Kim J., Kim C., Kim S., Yoon J. A review of chlorine evolution mechanism on dimensionally stable anode (DSA $\left.{ }^{\circledast}\right)$. Korean Chemical Engineering Research, 2015, vol. 53, pp. 531539.

6. Cornell A., Hakansson B., Lindbergh G. Ruthenium based DSA ${ }^{\circledR}$ in chlorate electrolysis-critical anode potential and reaction kinetics. Electrochimica Acta, 2003, vol. 48, pp. 473-481.

7. Adams B., Tian M., Chen A. Design and electrochemical study of $\mathrm{SnO}_{2}$-based mixed oxide electrodes. Electrochimica Acta, 2009, vol. 54, pp. 1491-1498.

8. Yao P., Chen X., Wu H., Wang D. Active $\mathrm{Ti} / \mathrm{SnO}_{2}$ anodes for pollutants oxidation prepared using chemical vapor deposition. Surface and Coatings Technology, 2008, vol. 202, pp. 3850-3855.
9. Neodo S., Rosestolato D., Ferro S., De Battisti A. On the electrolysis of dilute chloride solutions: influence of the electrode material on Faradaic efficiency for active chlorine, chlorate and perchlorate. Electrochimica Acta, 2012, vol. 80, pp. 282-291.

10. Czarnetzki L., Janssen L.J.J. Electrochemical oxidation of hypochlorite at platinum anodes. Electrochimica Acta, 1988, vol. 33, pp. 561-566.

11. Hansen H.A., Man I.C., Studt F., Abid-Pedersen F., Bligaard T., Rossmeisl J. Electrochemical chlorine evolution at rutile oxide (110) surfaces. Physical Chemistry Chemical Physics, 2010, vol. 12, pp. 283-290.

12. Girenko D.V., Velichenko A.B. Sintez nizkokontsentrirovannykh rastvorov gipokhlorita natriya $\mathrm{v}$ elektrolizerakh bez razdeleniya mezhelektrodnogo prostranstva [Synthesis of low concentration solutions of sodium hypochlorite in an electrolyzer with undivided electrode space]. Voprosy Khimii i Khimicheskoi Tekhnologii, 2018, no. 4, pp. 82-91. (in Russian).

13. Shmychkova O., Luk'yanenko T., Amadelli R., Velichenko A. Electrodeposition of $\mathrm{Ni}^{2+}$-doped $\mathrm{PbO}_{2}$ and physicochemical properties of the coating. Journal of Electroanalytical Chemistry, 2016, vol. 774, pp. 88-94.

14. Girenko D.V., Gyrenko A.A., Nikolenko N.V. Potentiometric determination of chlorate impurities in hypochlorite solutions. International Journal of Analytical Chemistry, 2019, vol. 2019, article no. 2360420.

15. Girenko D.V., Velichenko A.B. Selection of the optimal cathode material to synthesize medical sodium hypochlorite solutions in a membraneless electrolyzer. Surface Engineering and Applied Electrochemistry, 2018, vol. 54, pp. 88-95. 